Jan Dominik Bogataj, Rajko Bratož, Alenka Cedilnik, David Movrin, Miran Špelič, Rafko Valenčič

\title{
Hieronymus noster - Slavicus. Odmevi Stridončanove dediščine v slovenski in širši slovanski kulturi
}

\author{
Hieronymus noster - Slavicus. \\ Echoes of the Stridonian's Legacy in the \\ Slovenian and Broader Slavic Culture
}

Notorični polemik, kakršen je bil zaživa, je sv. Hieronim poleg nedopovedljivega vpliva na duhovno obzorje Zahoda tudi v stoletjih, ki so sledila njegovi smrti, povzročil nemalo prepirov in kontroverz, pri čemer ima posebno mesto slovanska kultura. Izhajajoč iz gordijskega problema ubikacije Stridona, lociranja njegovega rojstnega kraja, ki še dandanes buri strokovne in laične duhove, so Hieronimu nekateri pripisovali zasluge pri nastanku starocerkvenoslovanske pisave, glagolice, spet drugi so ga povezovali z rimskim obredom liturgije v slovanskem jeziku, nekateri gorečneži v zgodovini pa so šli celo tako daleč, da so mu pripisali tudi slovansko kri.

Ob 1600. obletnici njegove smrti je med 23. in 27. oktobrom 2019 na Slovenski akademiji znanosti in umetnosti (SAZU) pod častnim pokroviteljstvom predsednika Republike Slovenije Boruta Pahorja potekal mednarodni simpozij z naslovom Hieronymus noster. Na pobudo zaslužnega profesorja dr. Rafka Valenčiča je organizacijo prevzel Inštitut za patristične študije Victorinianum na Teološki fakulteti UL v sodelovanju z več uglednimi domačimi (Oddelek za zgodovino in klasično filologijo Filozofske fakultete UL, SAZU, ZRC SAZU) in tujimi (Institut des Sources 
chrétienne, Univerza v Cádizu - mednarodna mreža Europa Renascens, projekt DANUBIUS na Université de Lille, fakulteta Artes Liberales Univerze v Varšavi, Oddelek za srednjeveške študije Srednjeevropske univerze na Dunaju CEU) znanstvenimi ustanovami. Povabilu organizacijskega odbora, v katerem je sodelovalo šest slovenskih in šest inozemskih članov, je sledil nesluten odziv zainteresirane svetovne akademske javnosti, kar je na koncu privedlo do kar 111 aktivnih udeležencev, ki so nastopili z referati, pri čemer so prevladovali mednarodni strokovnjaki (poleg 22 slovenskih kar 89 inozemskih sodelujočih iz 17 držav). S tako udeležbo je ljubljanski simpozij dodobra presegel konceptualno podoben kongres, ki je leta 2006 v Cardiffu na waleški univerzi potekal pod naslovom Jerome of Stridon: Religion, Culture, Society and Literature in Late Antiquity, in tako postal doslej največja znanstvena konferenca za hieronimijanske študije.

Tematsko je ljubljanski simpozij zajemal širok spekter znanstvenih področij, povezanih s Hieronimom, kot je to za kolosalno osebnost njegovih razsežnosti pričakovano: od historiografije, arheologije, klasične filologije pa vse do biblične eksegeze, teologije, hereziologije, patrologije itd. Ljubljanski oziroma bolje rečeno slovenski genius loci je simpoziju diktiral posebno noto, saj je bilo nekaj sekcij namenjenih ravno obravnavi Hieronimove dediščine v slovenski in širši slovanski kulturi. Znova je bil zastavljen problem lociranja njegovega rojstnega kraja Stridon, ki je do gotskega razrušenja, kot piše Hieronim sam, ležal na meji med rimskima provincama Panonija in Dalmacija. Kolektivni spomin nanj je utegnil med slovanskim ljudstvom - tudi na območju današnje Slovenije - obdržati češčenje tega velikega moža iz pozne antike, kar se še danes odraža v patrocinijih številnih cerkva. Pomembno vlogo na simpoziju so v okviru posebne sekcije - v skladu z žlahtno akademsko svobodomiselnostjo imeli tudi raziskovalci Hieronimove zapuščine znotraj hrvaške kulture, saj so nastopili nekateri najuglednejši hrvaški znanstveniki.

Kot »slovanski« sad simpozija v tej številki revije Edinost in dialog predstavljamo nekaj najbolj zanimivih prispevkov, ki obeležujejo bogato Hieronimovo kulturno dediščino med južnoslovanskimi slovanskimi narodi in na ta način zorijo v smeri ekumenskega in medsosedskega (mednarodnega) dialoga. Član Hrvaške akademije znanosti in umetnosti dr. Josip Bratulić podaja sintezni pregled prepletenosti Hieronimovega vpliva 
znotraj hrvaške kulture. Srbski cerkveni zgodovinar dr. Ivica Čairović analizira obravnavo Hieronima v srbski teološki literaturi 20. in 21. stoletja, posebej v misli vladike dr. Atanasija Jevtića. Delo Vita et Transitus Sancti Hieronymi, ki je imelo izreden vpliv na humanistično in renesančno občudovanje Hieronima, v luči poznosrednjeveške recepcije na vzhodno jadranski obali obravnava hrvaška znanstvenica Ines Ivić. Slovenska slavistka dr. Petra Stankovska se v svojem prispevku dotika Stridončevih homilij v cerkvenoslovanskih različicah brevirja iz 13. stoletja, dr. Leon Debevec s Fakultete za arhitekturo UL pa predstavlja zgodovinski kontekst in arhitekturno analizo dvanajstih slovenskih cerkva, posvečenih sv. Hieronimu.

Pričujoči tematski sklop prispevkov tako zapolnjuje vrzel slovenske strokovne literature v proučevanju Hieronimovega vpliva na slovensko (slovansko) kulturo, pri čemer nas, poleg redkih izjem, naši južni sosedje neprimerljivo prekašajo, s tem pa želi tudi v slovenskem prostoru buditi zavest o živi dediščini enega največjih mož, kar jih je prišlo z našega področja, katerega vpliv je bil integralno povezan z zgodovino našega območja. V tej zvezi lahko napotimo na zanimivo nedavno študijo Julije Verkholansteve (2014) The Slavic Letters of St. Jerome. The History of the Legend and its Legacy, or, How the Translator of the Vulgate Became an Apostle of the Slavs (DeKalb, IL: Northern Illinois University Press), ki obširno obravnava to hieronimijansko tradicijo znotraj slovanske kulture.

Kljub mitični genezi legende o Hieronimovih slovanskih koreninah in o njegovem prispevku k oblikovanju slovanske kulture - kar je bilo kot obramba proti zavojevalskim kulturnim in represivnim cerkvenim težnjam že od 10. stoletja naprej plod srednjeveških, pretežno hrvaških intelektualcev, braniteljev lastne identitete, ki so kot vrhunec svojega prizadevanja leta 1248 na prošnjo senjskega škofa Filipa pri papežu Inocencu IV. dosegli, da je Hieronima priznal za izumitelja glagolice in dovolil glagolsko bogoslužje znotraj rimskega obreda - ima plemenita cirilmetodovska tradicija, ki se je naslonila prav na sv. Hieronima, danes širšo prepoznavnost, ki naj tudi pri Slovencih budi več ponosa in zanimanja.

Moto simpozija - Hieronymus noster - ki ga je skoval že ilirski kronist Marcellinus Comes v zgodnjem 6. stoletju, obenem pa nastopa tudi kot parafraza Hieronimovega epiteta za svojega »rojaka« Viktorina Ptujskega s pridevnikom noster, naš, niti najmanj ne želi segati na polje nacionalističnih 
apropriacijskih teženj, ki objektivno historiografijo maličijo na račun potrjevanja lastne identitete, marveč, prav nasprotno, odraža univerzalistično težnjo skupne dediščine, ki nas lahko povezuje. Hieronim kot vir quadrilinguis, ki je poleg latinščine, grščine in hebrejščine znal tudi sirsko (t. i. kaldejsko), v svojem sicer bogatem jezikovnem repertoarju ni imel stare slovanščine, marveč je bil s strani slovanske kulture "posvojen« kasneje. A s svojim izjemnim prevodnim delom je na neki način za štiri stoletja prehitel sveta solunska brata, saj so vsi trije goreli za prenos razumevanja Božje besede v razumljivem jeziku. Črkarska pravda glede azbuke stridonskemu zaljubljencu v Besedo, kljub temu da ob poznavanju številnih drugih črk pisave, imenovane po njem (littera Hieronymiana), ni obvladal, navsezadnje kar pristoji.

The present thematic issue of the journal encompasses the papers on the St. Jerome's influence on the Slovenian and Slavic culture, presented at the international symposium Hieronymus noster, which took place between October 23 and 27 in Ljubljana, at the Slovenian academy of sciences and arts, under the honorary patronage of Mr Borut Pahor, the President of the Republic of Slovenia. Among over 110 participants, some of the scholar present there spoke during different sections dedicated to the Slovenian and Slavic reception of Jerome's works and of him as an outstanding authority, especially in the Middle ages, when he had a very important role in guarantying the independence of Old Church Slavic language, Glagolitic script and the liturgy in this language. The symposium mottoHieronymus noster - which was forged by the $\sigma^{\text {th }}$ century Illyrian chronicler Marcellinus Comes, but stands also as a paraphrase of Jerome's own epithet given to his "compatriot"Victorinus of Poetovio, is nowhere near any nationalistic tendencies, grabbing hold of his figure and abusing historiography for achieving self-affirmation of one's own identity, but contrarily, the adjective noster expresses a universalistic aptness of appreciation of the common heritage in order to foster creativity and dialog in today's society. St. Jerome, vir quadrilinguis, who knew Latin, Greek, Hebrew and Syriac, was certainly not familiar with Old Slavonic language, but nonetheless, as a predecessor of St. Cyril and Methodius in transmitting the Bible in the vernacular languages and as a great lover of the Word, despite not knowing the Glagolitic script, assuredly did represent and still can symbolize an inspiration for different Slavic cultures. 